\title{
Efektivitas Fungsi Pengawasan Dalam Pendistribusian Raskin Di Desa Tetehosi I Kecamatan Gunungsitoli Idanoi
}

\author{
Maria Magdalena Bate'e \\ Sekolah Tinggi Ilmu Ekonomi Pembangunan \\ Maria.batee82@gmail.com
}

Nov Elhan Gea

STIE Pembangunan Nasional

elhangea@gmail.com

\begin{abstract}
Abstrak Pengawasan pada dasarnya diarahkan sepenuhnya untuk menghindari adanya kemungkinan penyelewengan atau penyimpangan atas tujuan yang akan dicapai. Pengawasan adalah proses penentuan apa yang akan dicapai sesuai dengan standar yang berlaku, apa yang sedang dilakukan, bagaimana menilai pelaksanaannya, dan bilamana perlu mengambil tindakan yang korektif. Tujuan dari penelitian ini untuk mengetahui efektivitas fungsi pengawasan pendistribusian Raskin di Desa Tetehosi I Kecamatan Gunungsitoli. Ditinjau dari karakteristik masalah maka dalam penelitian ini menggunakan jenis penelitian Deskriptif dengan pendekatan kualitatif. Dalam penelitian ini yang menjadi populasinya adalah seluruh masyarakat Desa Tetehosi I Kecamatan Gunungsitoli Idanoi Kota Gunungsitoli yang terdiri atas keluarga miskin dengan jumlah 313 kepala keluarga, dan yang menjadi sampel adalah bagian dari populasi dengan menggunakan teknik pengambilan sampel purposive sampling yang berarti sampel diambil dengan ketentuan peneliti karena adanya pertimbangan tertentu. Sementara data yang diperlukan adalah bersumber dari data primer dan data sekunder. Dari hasil penelitian bahwa fungsi pengawasan pendistribuasian Raskin di Desa Tetehosi I Kecamatan Gunungsitoli Idanoi telah dilakukan secara efektif dan sesuai dengan Pedoman Umum Raskin tahun 2016.
\end{abstract}

Kata Kunci Fungsi Pengawasan, Pendistribusian Raskin

\section{PENDAHULUAN}

Pada dasarnya pengawasan dilakukan untuk menghindari kemungkinan terjadinya suatu penyimpangan ataupun penyelewengan atas tujuan yang hendak dicapai. Pimpinan perlu melakukan pengawasan karena dengan adanya pengawasan maka dapat mengetahui sejauh mana pimpinan telah menjalankan kebijakannya dan apakah ada penyelewengan dari suatu pekerjaan di bawah kepemimpinannya. Dalam suatu perusahaan pengawasan merupakan salah satu fungsi dalam manajemen suatu organisasi karena pengawasan adalah proses mengawasi dan mengevaluasi suatu kegiatan. Pengawasan yang berkualitas adalah merupakan suatu kegiatan yang dilakukan secara positif dan sesuai dengan yang diharapkan oleh pegawai.

Menurut Rahman Mulyawan (2011: 64) mengatakan bahwa "pengawasan adalah proses pengamatan dari pada pelaksanaan seluruh kegiatan organisasi untuk menjamin agar semua pekerjaan yang sedang dilaksanakan berjalan sesuai dengan rencana yang telah ditentukan sebelumnya." Jadi secara umum pengawasan dapat menentukan apa yang akan dicapai, yang hendak dilaksanakan dan sesuai dengan standar yang diberlakukan. Pengawasan terhadap pendistribusian sangat penting dilakukan karena dalam hal pendistribuasian rentan terjadinya penyelewengan. Pendistribusian adalah kegiatan yang dilakukan untuk mempermudah penyampaian produk dan jasa dari produsen ke konsumen yang dituju. Menurut Alma (2010: 45 ) bahwa "pendistribusian adalah sekumpulan lembaga yang saling terhubung antara satu dengan yang lainnya dalam melakukan kegiatan penyaluran barang atau jasa sehingga tersedia untuk dipergunakan oleh konsumen." Salah satu contoh pendistribusian yang perlu diawasi adalah pendistribusian beras miskin (raskin). 
Kejadian nyata yang terjadi secara umum adalah efektivitas fungsi pengawasan terhadap pendistribusian raskin masih sangat minim. Ini dibuktikaan dengan masih ditemukannya permasalahan seperti mutu beras yang kurang baik, meskipun pemerintah menjamin bahwa beras miskin berkondisi baik, namun keluarga-keluarga yang menerima raskin tersebut mengeluhkan bahwa beras tersebut bau, kotor, dan berkutu. Selain itu masalah yang terjadi karena minimnya fungsi pengawasan adalah pendataan penerima manfaat. Sering ditemukan bahwa penerima manfaat raskin yang seharusnya adalah keluargakeluarga miskin dan tidak mampu justru diberikan kepada keluarga-keluarga sejahtera bahkan petugas di lapangan memprioritaskan sasarannya kepada keluarga-keluarga dekat yang sesungguhnya memiliki perekonomian yang mampu. Ditemukan lagi adanya pengutipan biaya tebusan raskin dari penerima manfaat yang tidak sesuai dengan hasil musyawarah desa bahkan bila ada keluarga miskin yang tidak mampu menebus biaya raskin maka pengelola atau pokja mengalihkan dan menjualnya kepada pihak lain seperti pedagang sembako. Ini berarti pendistribusian raskin amat rentan terhadap peyelewengan dan manipulasi. Apabila fungsi pengawasan terhadap pendistribusian raskin ini tidak dijalankan dengan baik maka akan sangat merugikan negara atas subsidi beras miskin.

Desa Tetehosi I adalah salah satu desa yang berada di wilayah Kecamatan Gunungsitoli Idanoi Kota Gunungsitoli yang memiliki jumlah penduduk sebanyak 3741 jiwa. Adapun Pendistribusian beras miskin di desa ini telah dilaksanakan sebagaimana prosedur pendistribusian raskin. Pengawasan dilakukan oleh Perum Bulog dan juga oleh aparat desa bahkan masyarakat desa secara umum juga ikut mengawasi sehingga fungsi pengawasan boleh dikatakan cukup berjalan, akan tetapi masih perlu ditingkatkan supaya fungsi pengawasan terhadap pendistribusian raskin dapat berjalan secara efektif. Sehingga dengan berjalannya fungsi pengawasan secara efektif maka akan meminimalisir terjadinya penyelewengan dan sasaran penerima raskin juga tepat. Hal ini sejalan dengan yang dikatakan oleh Winardi (2000: 23) bahwa "pengawasan yang efektif adalah pengawasan yang tidak hanya melihat sesuatu dengan seksama dan melaporkan hasil dari kegiatan mengawasi, akan tetapi juga memperbaiki dan meluruskannya sehingga mencapai tujuan yang sesuai dengan apa yang direncanakan." Dan selanjutnya oleh Mardiasmo (2005: 11) mengatakan bahwa "Efektivitas adalah ukuran berhasil tidaknya suatu organisasi mencapai tujuannya."

\section{LANDASAN TEORI}

\section{Pengertian Manajemen}

Pengertian manajemen diungkapkan oleh beberapa ahli, diantaranya adalah :

Menurut Sapre dalam Usman (2013: 6), "Manajemen adalah serangkaian kegiatan yang diarahkan langsung penggunaan sumberdaya organisasi secara efektif dan efisien dalam rangka mencapai tujuan organisasi."

Menurut Daft dalam Wibowo (2016: 7), mengatakan bahwa "Manajemen adalah pencapaian tujuan organisasional dengan cara yang efektif dan efisien melalui perencanaan, pengorganisasian, memimpin dan mengawasi sumberdaya organisasional."

Menurut Malayu S.P. Hasibuan (2011: 2), "Manajemen adalah Ilmu dan seni yang mengatur proses pemanfaatan sumber daya manusia dan sumber-sumber lainnya secara efektif dan efisian untuk mencapai tujuan tertentu."

Dari beberapa pengertian di atas maka dapat disimpulkan bahwa manajemen adalah suatu proses yang dijalankan oleh organisasi dalam hal penggunaan sumber daya manusia untuk mencapai tujuan organisasi secara efektif dan efisien.

\section{Fungsi-Fungsi Manajemen}

Fungsi manajemen adalah serangkaian kegiatan yang dijalankan dalam manajemen berdasarkan fungsinya masing-masing dan mengikuti satu tahapan-tahapan tertentu dalam pelaksanaannya. Fungsifungsi manajemen sebagaimana diterangkan oleh Nickels, McHugh and McHugh (1997) dalam bukunya Erni Trisnawati Sule dan Kurniawan Saefullah (2005: 318), terdiri dari empat fungsi, yaitu :

1. Perencanaan (Planning), yaitu proses yang menyangkut upaya yang dilakukan untuk mengantisipaasi kecenderungan di masa yang akan datang dan penentuan strategi dan taktik yang tepat untuk mewujudkan target dan tujuan organisasi.

2. Pengorganisasian (Organizing), yaitu proses yang menyangkut bagaimana strategi dan taktik yang telah dirumuskan dalam perencanaan didesain dalam sebuah struktur organisasi yang tepat dan 
tanggunh, sistem dan lingkungan organisasi yang kondusif, dan bisa memastikan bahwa semua pihak dalam organisasi bisa bekerja secara efektif dan efisien guna pencapaian organisasi.

3. Pengimplementasian (Directing), yaitu proses implementasi program agar bisa dijalankan oleh seluruh pihak dalam organisasi serta proses memotivasi agar semua pihak tersebut dapat menjalankan tanggungjawabnya dengan penuh kesadaran dan produktivitas yang tinggi.

4. Pengawasan (Controlling), yaitu proses yang dilakukan untuk memastikan seluruh rangkaian kegiatan yang telah direncanakan, diorganisasikan, dan diimplementasikan bisa berjalan sesuai dengan target yang diharapkan sekalipun berbagai perubahan terjadi dalam lingkungan dunia bisnis yang dihadapi.

\section{Fungsi Pengawasan}

Beberapa pengertian pengawasan telah dikemukakan oleh banyak penulis di bidang manajemen dalam bukunya Erni T. Sule dan Saefullah Kurniawan (2005: 317), diantaranya adalah Schermerhorn (2002) mendefinisikan "pengawasan sebagai proses dalam menetapkan ukuran kinerja dan pengambilan tindakan yang dapat mendukung pencapaian hasil yang diharapkan sesuai dengan kinerja yang telah ditetapkan tersebut." Berdasarkan pengertian ini, Schermerhorn menekankan fungsi pengawasan pada penetapan standar kinerja dan tindakan yang harus dilakukan dalam rangka pencapaian kinerja yang telah ditetapkan. Penjelasan ini sejalan dengan pengertian pengawasan menurut Stoner, Freeman, dan Gilbert (2000) dimana menurut mereka "Control is the process of ensuring that actual activities conform the planned activities." Jadi, pengawasan adalah proses untuk memastikan bahwa segala aktivitas yang terlaksana sesuai dengan apa yang telah direncanakan.

Secara lebih lengkap, Stoner, Freeman, dan Gilbert (2000) masih dalam bukunya Erni T. Sule (2005: 318) mengemukakan fungsi pengawasan sebagai a systematic effort to set performance standars with planning objectives, to design information feedback systems, to compare actual performance with these predetermined standards, to determine whether there are any deviations and to measure their significance, and to take any action required to assure that all corporate objectives." Artinya bahwa pengawasan adalah upaya sistematis dalam menetapkan standar kinerja dan berbagai tujuan yang direncanakan, mendesain sistem informasi umpan balik, membandingkan antar kinerja yang dicapai dengan standar yang telah ditetapkan sebelumnya, menentukan apakah terdapat penyimpangan dan tingkat signifikansi dari penyimpangan tersebut, dan mengambil tindakan yang diperlukan untuk memastikan bahwa seluruh sumber daya perusahaan dipergunakan secara efektif dan efisien dalam pencapaian tujuan perusahaan. Adapun tujuan dari fungsi pengawasan yaitu :

1. Adaptasi Lingkungan. Tujuan pertama dari fungsi pengawasan adalah agar perusahaan dapat terus beradaptasi dengan perubahan yang terjadi di lingkungan perusahaan, baik lingkungan yang bersifat internal maupun lingkungan eksternal.

2. Meminimumkan Kegagalan. Ketika perusahaan melakukan kegiatan produksi misalnya, perusahaan berharap agar kegagalan seminimal mungkin.

3. Meminimumkan Biaya. Fungsi pengawasan melalui penetapan standar tertentu dalam meminimumkan kegagalan dalam produksi misalnya, akan dapat meminimumkan biaya yang harus dikeluarkan oleh perusahaan.

4. Antisipasi Kompleksitas Organisasi. Tujuan terakhir dari fungsi pengawasan adalah agar perusahaan dapat mengantisipasi berbagai kegiatan organisasi yang kompleks.

Agar keempat tujuan dari fungsi pengawasan tersebut dapat lebih dipahami maka ditetapkan langkahlangkah dari proses pengawasan sehingga kaitan antara apa yang dikerjakan oleh perusahaan dengan fungsi pengawasan akan lebih dapat dipahami. Langkah-langkah tersebut digambarkan dalam gambar 2.1 berikut ini : 


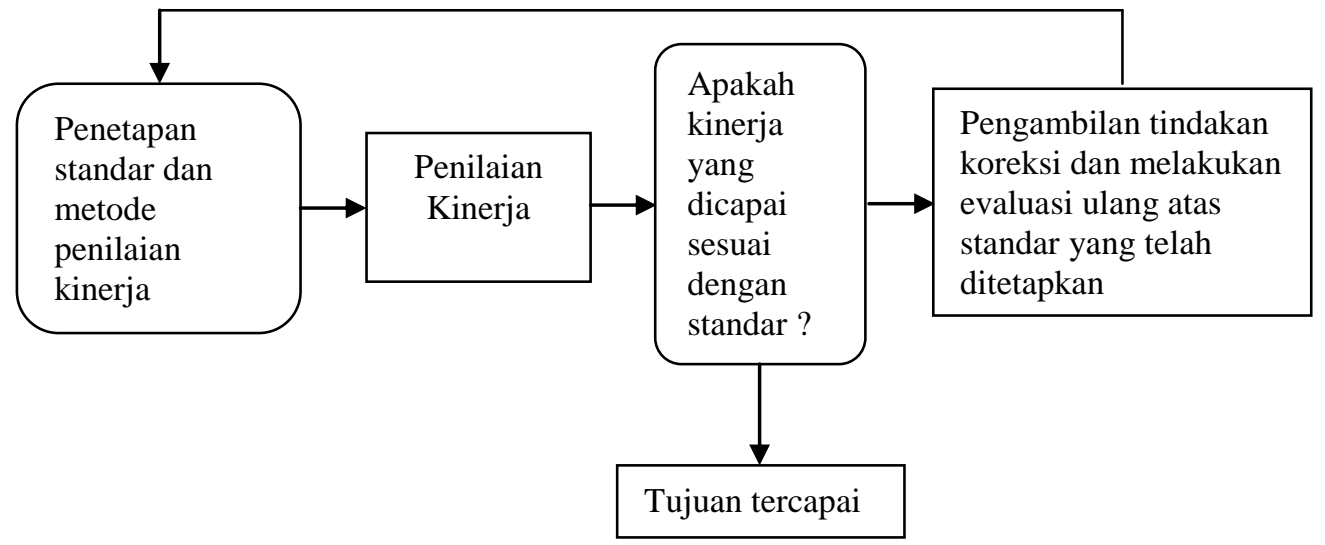

Gambar 2.1. Tahap-tahap dalam proses pengawasan

Dari gambar di atas menjelaskan bahwa langkah pertama adalah penetapan standar sebaiknya dilakukan pada saat perencanaan dilakukan. Setelah ditetapkan penetapan standar maka dilakukan penilaian kinerja untuk membandingkan kinerja yang dicapai dengan tujuan dan standar yang telah ditetapkan semula dan penilaian kinerja ini dilakukan secara terus-menerus. Setelah ditetapkan bahwa yang akan dinilai contohnya adalah tingkat penjualan setiap satu tahun sekali oleh manajer penjualan maka pada tahap ketiga manajer penjualan akan melakukan perbandingan dari apa yang telah diperoleh di bagian penjualan dengan standar yang telah ditetapkan. Apabila kinerja berada di bawah standar berarti perusahaan mendapatkan masalah, oleh karena itu perusahaan kemudian perlu melakukan pengendalian yaitu dengan mencari jawaban mengapa masalah tersebut terjadi disinilah perusahaan melakukan berbagai tindakan untuk mengoreksi masalah tersebut.

\section{Pengertian dan Jenis-Jenis Saluran Distribusi}

Menurut Mursid (2003: 85), "saluran distribusi adalah lembaga-lembaga penyalur yang mempunyai kegiatan untuk menyalurkan atau menyampaikan barang-barang atau jasa-jasa dari produsen ke konsumen." Dari pengertian tersebut maka menunjukkan bahwa setiap perusahaan baik yang bergerak dibidang industri maupun dibidang non industri harus melaksanakan fungsi saluran distribusi. Setiap perusahaan bebas memilih saluran distribusinya yang terpenting adalah kegiatan penyampaian produk sampai ke tangan konsumen tepat pada waktunya. Adapun jenis-jenis saluran distribusi terdiri dari :

1. Produsen - Konsumen. Ini adalah saluran yang paling pendek dan paling sederhana yaitu tanpa melalui perantara.

2. Produsen - Pengecer - Konsumen. Jenis saluran distribusi ini dimana pengecer besar langsung melakukan pembelian pada produsen dan selanjutnya menjual kepada konsumen.

3. Produsen - Pedagang Besar - Pengecer - Konsumen. Saluran seperti ini banyak digunakan oleh produsen dan dinamakan sebagai saluran distribusi tradisional. Disini produsen hanya melayani penjualan dalam jumlah besar kepada pedagang besar saja, tidak menjual kepada pengecer.

4. Produsen - Agen - Pengecer - Konsumen. Disini produsen memilih agen sebagai penyalurnya. Dia menjalankan kegiatan perdagangan yang besar dalam saluran distribusi yang ada dengan sasaran penjualannya ditujukan kepada pengecer besar.

5. Produsen - Agen - Pedagang Besar - Pengecer - Konsumen. Dalam saluran distribusi produsen sering menggunakan agen sebagai perantara untuk menyalurkan barangnya kepada pedagang besar yang kemudian menjualnya kepada pengecer yaitu toko-toko kecil.

\section{METODOLOGI PENELITIAN}

Penelitian merupakan suatu proses kegiatan dalam rangka mencari, mengetahui dengan tujuan agar menemukan suatu ilmu pengetahuan dengan cara ilmiah dan tersusun secara sistematis. Tujuan dari penelitian ini untuk mengetahui efektivitas fungsi pengawasan pendistribusian Raskin di Desa Tetehosi I Kecamatan Gunungsitoli. Ditinjau dari karakteristik masalah maka dalam penelitian ini menggunakan 
jenis penelitian Deskriptif dengan pendekatan kualitatif. Dalam penelitian ini yang menjadi populasinya adalah seluruh masyarakat Desa Tetehosi I Kecamatan Gunungsitoli Idanoi Kota Gunungsitoli yang terdiri atas keluarga miskin dengan jumlah 313 kepala keluarga, dan yang menjadi sampel adalah bagian dari populasi dengan menggunakan teknik pengambilan sampel purposive sampling yang berarti sampel diambil dengan ketentuan peneliti karena adanya pertimbangan tertentu. Sementara data yang diperlukan adalah bersumber dari data primer dan data sekunder. Data primer yaitu data yang langsung diperoleh dari objek penelitian dengan cara pengamatan langsung dan wawancara, sedangkan data sekunder adalah data yang dikumpulkan secara tidak langsung dengan menggunakan sumber lain contohnya jurnal ilmiah, dokumen-dokumen yang berkaitan dengan masalah yang diteliti, dan lain-lain.

\section{HASIL PENELITIAN}

Hasil pengolahan data dari pengamatan langsung di objek penelitian dan juga dari wawancara dengan responden, maka hasil penelitian adalah sebagai berikut :

1. Desa Tetehosi I Kecamatan Gunungsitoli Idanoi adalah desa yang memiliki jumlah penduduk yang sangat banyak yaitu 3741 jiwa yang terdiri atas 532 kepala keluarga, dan dari jumlah kepala keluarga tersebut terdapat 313 kepala keluarga yang terdaftar sebagai Rumah Tangga Miskin (RTM) atau penerima manfaat beras miskin.

2. Mekanisme penyaluran Raskin terlebih dahulu ditetapkan pagu Raskin. Penetapan pagu Raskin mengacu pada pagu Raskin Kabupaten/Kota yang disampaikan oleh Menko Kesra. Di Desa Tetehosi I, penetapan penerima manfaat Raskin adalah melalui data sensus penduduk yang telah dilaksanakan pada tahun 2016. Berdasarkan pagu Raskin tersebut, walikota Gunungsitoli menunjuk pejabat untuk menerbitkan Surat Perintah Alokasi (SPA), dengan diterbitkannya SPA maka Perum Bulog menerbitkan Surat Perintah Penyerahan Barang (SPPB) dan sesuai dengan SPPB maka Perum Bulog menyalurkan sampai di Titik Distribusi (TD) yaitu Desa Tetehosi I Gunungsitoli Idanoi. Pada saat raskin telah tiba di TD dilakukan serah terima dan ditandatangani oleh kedua belah pihak yakni Satuan Kerja Raskin dengan Tim Koordinasi Raskin dan dibuatkan berita acara.

3. Desa Tetehosi I Kecamatan Gunungsitoli Idanoi membentuk kelompok kerja (Pokja) yang berfungsi sebagai pelaksana dalam mendistribusikan Raskin. Pokja ini terdiri atas Kepala Desa, Sekretaris, dan Kepala Urusan Umum. Dalam hal pendistribusian ke dusun-dusun dibantu oleh kepala dusun.

4. Subsidi beras yang diterima oleh rumah tangga sasaran penerima manfaat(RTS-PM) raskin adalah sebesar $15 \mathrm{~kg}$ dan bessarnya harga tebusan raskin (HTR) untuk raskin tersebut adalah Rp 1.600/kg. HTR disampaikan oleh Pokja kepada RTS-PM raskin. HTR tersebut dibayarkan secara tunai kepada petugas pendistribusi raskin yang kemudian petugas tersebut menyerahkannya Pokja desa yang selanjutnya ke Pokja kecamatan untuk disetorkan ke Perum Bulog.

5. Efektivitas Fungsi pengawasan dalam mendistribusikan beras miskin tercermin dalam indikator $6 \mathrm{~T}$ pendistribusian Raskin, yaitu :

a. Tepat sasaran penerima manfaat.

Fungsi pengawasan terlaksana pada saat menyalurkan raskin. Pada pendataan awal jumlah kepala keluaraga miskin adalah 313 keluarga, dan realita di lapangan terealisasi 80\% menerima raskin. Sisanya yang $20 \%$ adalah karena keterlambatan membayar HTR.

b. Tepat Jumlah

Jumlah besar Raskin yang telah ditentukan kepada masyarakat Desa Tetehosi I Kecamatan Idanoi yang di data menjadi RTS-PM adalah sebanyak $15 \mathrm{~kg}$ per RTS setiap bulan selama 12 (dua belas) kali dalam setahun. Penentuan jumlah ini telah sesuai dengan Pedoman Umum Raskin tahun 2016.

c. Tepat Harga

Fungsi pengawasan dalam hal penentuan harga sudah efektif sesuai dengan buku Pedoman Umum Raskin tahun 2016 adalah Rp 1.600/kg. Biaya operasional petugas yang menyalurkan langsung raskin tersebut ke RTS-PM diambil dari dana desa sesuai dengan hasil musyawarah desa.

d. Tepat Waktu

Pembagian raskin kepada RTS-PM sudah sesuai dengan buku Pedoman Umum Raskin tahun 2016 yaitu setiap bulan untuk 12 kali dalam setahun

e. Tepat Administrasi

Terpenuhinya persyaratan administrasi secara benar salah satunya adalah membawa Kartu Perlindungan Sosial (KPS) dan fungsi pengawasannya adalah mengawasi dengan cermat data 
yang tertera dalam KPS tersebut agar tidak disalahgunakan dan untuk mengetahui apakah KPS tersebut adalah benar sesuai titik distribusi di Desa Tetehosi I Kecamatan Idanoi.

f. Tepat Kualitas

Fungsi pengawasan pada kualitas beras adalah sebelum mendistribusikan raskin tersebut kepada RTS-PM maka terlebih dahulu di cek apakah beras tersebut baik, tidak bau dan tidak kotor.

\section{KESIMPULAN}

a. Kesimpulan

- Pendistribusian Raskin terlebih dahulu Walikota Gunungsitoli menunjuk pejabat untuk menerbitkan Surat Perintah Alokasi (SPA), dengan diterbitkannya SPA maka Perum Bulog menerbitkan Surat Perintah Penyerahan Barang (SPPB) dan sesuai dengan SPPB maka Perum Bulog menyalurkan sampai di Titik Distribusi (TD) yaitu Desa Tetehosi I Gunungsitoli Idanoi. Pada saat raskin telah tiba di TD dilakukan serah terima dan ditandatangani oleh kedua belah pihak yakni Satuan Kerja Raskin dengan Tim Koordinasi Raskin dan dibuatkan berita acara.

- Fungsi pengawasan dilakukan oleh Badan Pengawasan Keuangan dan Pembangunan (BPKP), tim koordinasi raskin, dan pokja Desa Tetehosi I Kecamatan Gunungsitoli Idanoi.

- Fungsi pengawasan pendistribusian Raskin di Desa Tetehosi I Kecamatan Gunungsitoli Idanoi telah dilakukan secara efektif ini tercermin dari indikator pendistribusian Raskin.

b. Saran

- Efektivitas fungsi pengawasan terhadap penerima manfaat Raskin di Desa Tetehosi I Kecamatan Gunungsitoli Idanoi disarankan supaya terus ditingkatkan.

- Dalam hal pendataan RTS-PM disarankan agar aparat Desa benar-benar mendata masyarakat yang sebenarnya layak untuk menerima raskin.

- Pokja Desa Tetehosi I Kecamatan Gunungsitoli Idanoi hendaknya mengecek kualitas beras sebelum disalurkan kepada RTS-PM Desa Tetehosi I Kecamatan Gunungsitoli Idanoi dan dalam hal menentukan biaya operasional disarankan kepada Pokja agar menyesuaikan dengan kemampuan masyarakat.

- Bagi masyarakat yang tidak melunasi HTR disarankan diberikan sanksi agar tidak menjadi hambatan bagi desa lain yang juga menjadi penerima manfaat raskin.

\section{UCAPAN TERIMA KASIH}

Dalam penulisan penelitian ini tidak terlepas dari dukungan saran atau sumbangsih pemikiran serta bantuan dari beberapa pihak baik secara langsung maupun tidak langsung. Untuk itu, Penulis menyampaikan ucapan terima kasih kepada :

1. Ketua STIE Pembangunan Nasional.

2. Rekan-rekan Dosen di STIE Pembangunan Nasional.

3. Pengelola JESYA STIE Al-Washliyah Sibolga yang telah berkenan menerima penelitian ini.

4. Suami dan anak yang selalu mendukung dalam doa untuk keberhasilan penelitian ini.

\section{DAFTAR PUSTAKA}

Alma, (2010). Manajemen Pemasaran dan Pemasaran Jasa. Bandung: Alfabeta

Bulog, (2016). Pedoman Umum Subsidi Beras Bagi Masyarakat Berpendapatan Rendah 2016. Kementerian Koordinator Bidang Pembangunan Manusia dan Kebudayaan Republik Indonesia

Hasibuan S.P. Malayu, (2011). Manajemen Dasar, Pengertian dan Masalah. Jakarta. Penerbit : Bumi Aksara. 
James AF. Stoner, R.Edward Freeman, Daniel R.Gilbert, (2000). Management. Jr.,International Edition.

John R. Schermerhorn, (2002). Manajemen. Jr., 7th Edition.

Mursid, (2003). Manajemen Pemasaran. Jakarta : Bumi Aksara

Sule T. Erni dan Saefullah Kurniawan, (2005). Pengantar Manajemen. Edisi Pertama. Jakarta. Penerbit : Kencana.

Sujarweni, V.Wiratna, (2015). Metode Penelitian Bisnis dan Ekonomi, Yogyakarta, Penerbit : BPFE.

Usman, (2013). Manajemen (Teori, Praktir, dan Riset Pendidikan). Edisi-4. Jakarta. Penerbit : Bumi Aksara

Warren J. Keegan, Manajemen Pemasaran Global, Jakarta : PT Indeks

Wibowo, (2016). Manajemen Kinerja. Cetakan ke-10. Jakarta : Rajawali

Winardi, (2000), Kepemimpinan Dalam Manajemen. Jakarta : Rineka Cipta 